\title{
確率的再構築・格子ボルツマン法を用いた固体酸化物形燃料電池 燃料極のモデリング*
}

\author{
鈴 江 祥 典*1, 鹿 園 直 毅*2, 笠木 伸 英*3 \\ Modeling of Solid Oxide Fuel Cell Anode Using \\ Stochastic Reconstruction and Lattice Boltzmann Method
}

Yoshinori SUZUE*4, Naoki SHIKAZONO and Nobuhide KASAGI

${ }^{*}$ Department of Mechanical Engineering, The University of Tokyo, 7-3-1 Hongo, Bunkyo-ku, Tokyo, 113-8656 Japan

\begin{abstract}
A novel modeling scheme of SOFC anodes based on the stochastic reconstruction technique and the Lattice Boltzmann method (LBM) is proposed and evaluated for the performance assessment and optimization of anode microstructures. Cross-sectional microscopy images are processed to obtain two-dimensional phase maps (i.e., Ni, YSZ and pore), of which two-point correlation functions are used to reconstruct a three-dimensional model microstructure. Then, the diffusivity, electrical conductivity and polarization resistance of the reconstructed anode are obtained through the LBM simulation. The predicted tortuosity factors of Ni phase are slightly larger than the experimental result. However, the predicted anodic polarization resistance is in good agreement with the literature data. Thus, the proposed method predicts the anode performance for a given microstructure, and is considered as a promising tool for designing SOFC anodes.
\end{abstract}

Key Words: Solid Oxide Fuel Cell, Image Processing, Computational Fluid Dynamics, Electrode

\section{1. 序觟}

固体酸化物形然料電池（Solid Oxide Fuel Cell: SOFC）は, 高い発電効率を有し多様な燃料を使用で きるために次世代電源として期待されている(1). さら に, SOFC の高温排気をマイクロガスタービンに利用 したハイブリッドシステムでは, システム全体で $65 \%$ 以上の高い発電効率が実現可能であることが示されて いる(2). しかし, セルの信頼性向上と材料コスト低減 のため作動温度の低下が求められており，低温作動時 の発電効率の改善が課題である.

種々の SOFC の中で最も発電効率に優れるとされる 燃料極支持型セル(3)では, 燃料極多孔質体の微細構造 が発電効率と信頼性に大きな影響を及ぼす，従来の研 究では, 燃料極材料である $\mathrm{Ni}$, YSZ 粒子径やその組 成比などを主なパラメータとし, 燃料極微細構造最適 化のための指針が提案されてきた (4)(5). しかし, サー メット構造からなる SOFC 燃料極の微細構造は, 焼成

\footnotetext{
* 原稿受付 2007 年 4 月 2 日.

*1 学生員, 東京大学大学院工学系研究科(业113-8656 東京都 文京区本郷 7-3-1).

*2 正員, 東京大学大学院工学系研究科.

*3 正員, フェロー, 東京大学大学院工学系研究科.

E-mail : suzue@thtlab.t.u-tokyo.ac.jp
}

時及び発電時の温度履歷により変化するため, 電極微 細構造の影響をこれらのパラメータのみから正確に議 論することは困難である.

一方, SOFC 電極をモデル化し数值解析により性能 を評価する研究も多数報告されている(6)(7). しかし, これらのモデルは比較的単純な電極微細構造を仮定し ており，実際の電極での観察・測定結果 ${ }^{(8)}$ との一致は 得られていない.

このような背景から, 焼成後の燃料極微細構造を詳 細に把握し, 性能評価を行うことが求められる. しか し, 対象とする燃料極は粒子径 $1 \mu \mathrm{m}$ 程度の微細かつ 複雑な構造を有するため, 三次元構造を直接的に観察 することは困難であり，長い測定時間を要する(9). 一

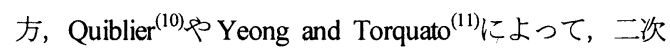
元画像から得られた構造統計量を基に三次元構造を計 算機上で再構築できることが示されており，多孔質体 の解析に広く応用されている(12).

本研究では, SOFC 燃料極の微細構造が発電性能に 及ぼす影響を詳細に評価するための数值解析手法を提 案する. 即ち, 多成分多孔質系に適した Yeong and Torquato $^{(11)}$ の再構築手法を用いることで SOFC 燃料極 の三次元構造を数值的に再構築する. さらに, 複雑構 造体内部の解析に適した格子ボルツマン法 (Lattice 
Boltzmann Method: LBM) ${ }^{(13) を}$ 用いて物質輸送と電気 化学反応の連成計算を行い, 燃料極構造モデル内の各 成分のネットワークの連続性, 発電性能の評価を行う. 本報では, 本解析手法の妥当性, 有用性を検討するた めに, 焼成温度が異なる燃料極試料の構造再構築と性 能評価を行った.

\section{主な記号}

\begin{tabular}{|c|c|}
\hline C & 体積モル濃度 $\left[\mathrm{mol} / \mathrm{m}^{3}\right]$ \\
\hline$D$ & 拡散係数 $\left[\mathrm{m}^{2} / \mathrm{s}\right]$ \\
\hline E & 再構築評価関数 \\
\hline$f_{i}$ & 速度分布関数 \\
\hline$f_{i}^{\text {qq }}$ & 平衡速度分布関数 \\
\hline$i$ & 電流密度 $\left[\mathrm{A} / \mathrm{m}^{2}\right]$ \\
\hline$i_{0}$ & 三相界面あたり交換電流 $[\mathrm{A} / \mathrm{m}]$ \\
\hline$i_{\text {reac }}$ & 体積あたり反応電流 $\left[\mathrm{A} / \mathrm{m}^{3}\right]$ \\
\hline$L$ & 計算領域長（電極厚さ）[ $[\mu \mathrm{m}]$ \\
\hline$L_{l}(r)$ & Lineal-path function \\
\hline$l_{\lambda}(r)$ & 線要素数 \\
\hline$L_{\mathrm{TPB}}$ & 体積あたり三相界面密度 $\left[\mathrm{m}^{-2}\right]$ \\
\hline$N_{\text {pixel }}$ & ピクセル数 \\
\hline$p$ & 圧力 $[\mathrm{Pa}]$ \\
\hline$R_{i j}(r)$ & 二点相関関数 \\
\hline$t^{*}$ & 緩和時間 \\
\hline$w_{i}$ & 単位時間反応生成量 \\
\hline$Z(\mathbf{x})$ & 成分関数 \\
\hline$\varepsilon$ & 体積分率 \\
\hline$\phi$ & 電位 [V] \\
\hline$\Gamma$ & Thiele 数 \\
\hline$\eta$ & 過電圧 [V] \\
\hline$\rho$ & 抵抗率 $[\Omega \mathrm{m}]$ \\
\hline$\sigma$ & 導電率 $\left[\mathrm{Sm}^{-1}\right]$ \\
\hline$\tau$ & 屈曲度ファクタ \\
\hline \multicolumn{2}{|c|}{ 添字 } \\
\hline eff & 多孔質体内での実効値 \\
\hline elec & 電子 \\
\hline ion & イオン \\
\hline $\mathrm{H}_{2}$ & 水素 \\
\hline $\mathrm{H}_{2} \mathrm{O}$ & 水蒸気 \\
\hline
\end{tabular}

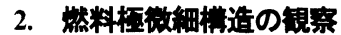

2.1 钼察試料の作成 燃料極材料には NiO-YSZ 混 合粒子（セイミケミカル, 平均粒子径 $1.5 \mu \mathrm{m}$ ）を用 いた. NiO, YSZ粒子の混合比は 60:40 wt\%である. 材料粒子をバインダと混練し，押し出し成形によりロ ッド状の試料を作成した（環境セラミックスリサー

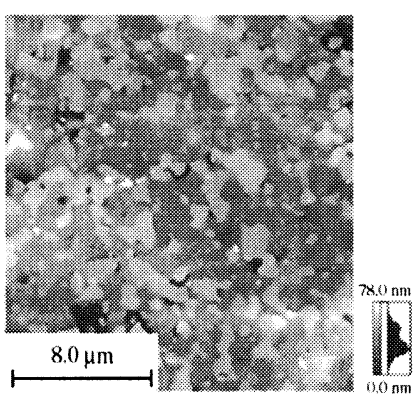

Fig. 1 Height image of a $1400^{\circ} \mathrm{C}$-sintered sample measured by a scanning probe microscope.

チ）、試料の作製は，現実的なセル作製条件を考慮し て行った. 各試料を $1000{ }^{\circ} \mathrm{C} て ゙ 3$ 時間仮焼した後, 試 料ごとに焼成温度を変えて 3 時間焼成した. 焼成温度 はそれぞれ $1300{ }^{\circ} \mathrm{C}, 1350{ }^{\circ} \mathrm{C}, 1400{ }^{\circ} \mathrm{C}$ した. 焼成 時の温度変化率は昇温, 降温ともに $10{ }^{\circ} \mathrm{C} / \mathrm{min}$ とした. その後, 高温水素雾囲気下 $\left(750{ }^{\circ} \mathrm{C}, \mathrm{H}_{2}: \mathrm{N}_{2}=67: 33\right)$ で 10 時間還元を行った. 各成分の原子量と密度から 計算される還元後の $\mathrm{Ni}, Y S Z$ の体積比は $42.4: 57.6$ で ある. 観察試料の空隙率は, 水銀ポロシメータ（島津 製作所，オートポア IV9500）で測定した $1200{ }^{\circ} \mathrm{C}$ 焼結 燃料極の空隙率の值から, 各温度での収縮率を基に計 算した. 計算された $1300,1350,1400{ }^{\circ} \mathrm{C}$ 焼結試料の空 隙率はそれぞれ 0.450,0.393,0.335であった。

還元後, 微細構造を損なわないよう低粘度エポキシ 樹脂を空隙内に真空含侵した. さらに, 後述の構造再 構築法で平滑な二次元断面画像が必要となるため, ダ イヤモンドペーストを用いて断面を研磨した. 走査型 プローブ顕微鏡（島津製作所，SPM9600，ダイナミッ クモード AFM）を用いて研磨後の試料断面を測定し, その平滑度を評価した. $1400{ }^{\circ} \mathrm{C}$ 焼結試料での測定結 果を図 1 に示す. 輝度が高い成分が YSZ 粒子であり, $\mathrm{Ni}$ 粒子と空隙は図からは識別できない, 測定された 試料の表面粗さは最大でも $80 \mathrm{~nm}$ 程度であり, 粒子径 と比較してほぼ平滑と見なせる. また, 樹脂の含侵が 不十分な空隙が確認されたが（図 1 黒色領域），その 周囲での粒子の変形が見られないためその影響は無視 した.

$2 \cdot 2$ 试料の锶察 試料断面の撮像には共焦点レーザ 顕微鏡（島津製作所, OLS3000, 1024 pixel $\times 768$ pixel）を用いた. 観察領域は $42 \mu \mathrm{m} \times 31.5 \mu \mathrm{m}$ であ り, 空間解像度は $41 \mathrm{~nm} / \mathrm{pixel}$ である. 得られた電極 断面画像の例を図 2(a) ( c) に示す. 輝度の高い順に Ni, YSZ, 空隙（樹脂）に対応寸る. 高温焼結条件下で $\mathrm{Ni}$, YSZ粒子の粒成長が顕著に進むことが確認できる. 


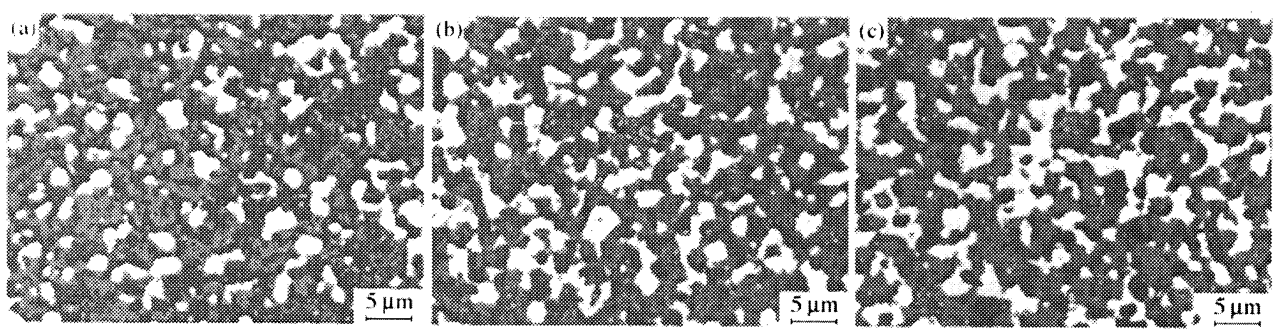

Fig. 2 Original cross-sectional images of sample anodes sintered at (a) $1300{ }^{\circ} \mathrm{C}$, (b) $1350{ }^{\circ} \mathrm{C}$ and (c) $1400{ }^{\circ} \mathrm{C}$.

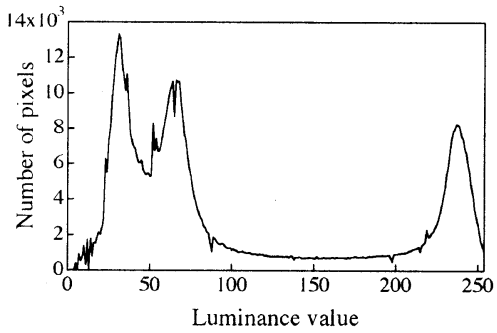

Fig. 3 Luminance histogram of a $1400{ }^{\circ} \mathrm{C}$ sintered sample.

\section{3. 三次元棤造の再模築}

$3 \cdot 1$ 二次元画像処理 空隙, YSZ, Ni の三相は図 3 に示すような輝度值の差から判别を行う。しかし，高 輝度な $\mathrm{Ni}$ 粒子の境界が不鮮明であるために, 元画像 から直接輪郭抽出を行うことは困難である. そのため, 従来研究(14)でも正確な輪郭抽出は成されていない，そ こで, 本研究では重み付き微分フィルタによる輪郭強 調を施した。 この補正画像に対し，三值化後の体積分 率が空隙率及び NiYYSZ 混合比から計算される各成分 の体積分率に合うように輝度值の閾値を設定し, 成分 判別を行った. $1400{ }^{\circ} \mathrm{C}$ で焼結した試料の成分判別画 像老図 4 に示寸. 図 2(c)の元画像との比較加ら, 上記 の手法によって適切な相判別がなされていることが確 認できる.

$3 \cdot 2$ 二次元画像解析 前節で相判別された二次元画 像データから, 各ピクセル $\mathbf{x}$ での成分関数 $Z(\mathbf{x})$ を次式 により定義する.

$$
Z(\mathbf{x})= \begin{cases}0 & \text { (for } \mathbf{x} \in \text { pore, black) } \\ 1 & \text { (for } \mathbf{x} \in \mathrm{YSZ}, \text { gray) } \\ 2 & \text { (for } \mathbf{x} \in \mathrm{Ni}, \text { white) }\end{cases}
$$

式(1)で定義した成分関数を用い，任意の二相 $i, j(i, j=0$ ２）が距離 $\boldsymbol{r}$ に存在する確率として二点相関を定義す る.

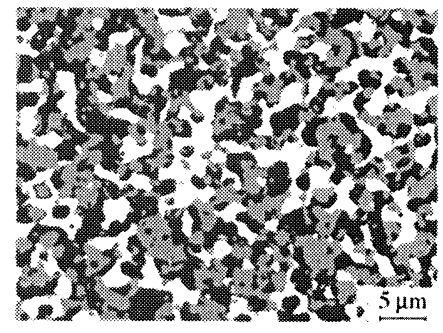

Fig. 4 Phase-distinguished image of a $1400{ }^{\circ} \mathrm{C}$ sintered sample (Ni: white, YSZ: gray, pore: black).

$R_{i j}(r)=\frac{\overline{\delta(Z(\mathbf{x}), i) \delta(Z(\mathbf{x}+\mathbf{r}), j)}}{\overline{\delta(Z(\mathbf{x}), i)}}$

ここで, $\delta$ はクロネッカーのデルタ関数を表す. また, 燃料極多孔質体は等方性を有し，二点相関は距離のみ の関数として表せると仮定した.

式(2)から計算された Ni-Ni 間, YSZ-YSZ 間の二点 相関の分布を図 5 に示寸. 式(2)の定義から, 二点相 関は十分遠方では各成分の体積分率に収束する，本研 究では撮像領域が十分大きくなかったために二点相関 が理論值（体積分率）まで十分収束していないが，体 積分率に対する誤差は $5 \%$ 以下と小さい. 焼結温度に よる収縮率の差に伴う各相の体積分率の変化から, 高 温で焼結された試料ほど固体成分の二点相関の值が大 きくなる. また, YSZ-YSZ 閒の二点相関がおよそ $2 \mu \mathrm{m}$ でほぼ収束するのに対し， Ni-Ni 閒の二点相関は $6 \mu \mathrm{m}$ 程度離れた点でも大きく変動する. このことから, 燃 料極内の YSZ は比較的均一に分散しているのに対し, $\mathrm{Ni}$ は特定スケールの不均一な構造を有していると考 えられる.

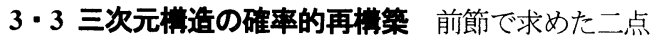
相関の值を用い, Yeong and Torquato の構造再構築法 ${ }^{(1)}$ を用いて三次元構造の再構築を行った. 格子間隔 $\Delta x$ は $0.178 \mu \mathrm{m}$ である. 計算領域は, 格子数（及び計算 領域長 $L)$ が $50(8.9 \mu \mathrm{m}), 100(17.8 \mu \mathrm{m})$ または $150(26.7$ $\mu \mathrm{m})$ の立方体領域とし, 計算領域サイズの影響を評価 した. 境界条件として, 全方向に周期境界条件を課し 

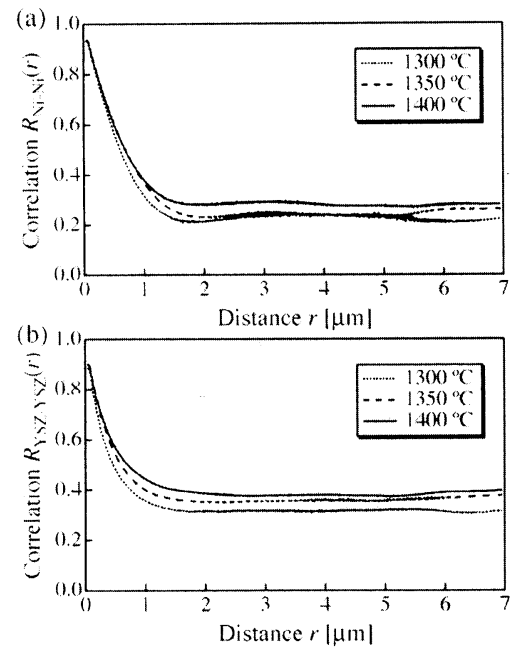

Fig. 5 Temperature dependence of two-point correlation functions of (a) Ni-Ni and (b) YSZ-YSZ.

た。まず，計算領域内のセルを各相の体積分率に応じ てランダムに三相に配分する. その後, Monte Carlo 法によって 2 点のセルを抽出し，その成分を交換する 操作を繰り返すことによって, 三次元構造の二点相関 $\left(R_{i j}{ }^{3 \mathrm{D}}\right)$ の値を目標とする二次元画像の二点相関 $\left(R_{i j}{ }^{2 \mathrm{D}}\right)$ に漸近させる. 収束過程の評価関数 $E$ は以下 の形で定義した。

$$
E=\sum_{i, j} \int_{0}^{r_{0}}\left\{R_{i j}^{3 \mathrm{D}}(r)-R_{i j}^{2 \mathrm{D}}(r)\right\}^{2} d r
$$

式(3)の)積分区間 $r_{0}$ は $7.0 \mu \mathrm{m}$ （40 格子相当）とした. また，等方性の仮定により，式(3)中の積分 $d r$ は $x, y$, z各軸一次元方向についてのみ計算した.

交換過程の各ステップにおいて, 評価関数 $E$ が前 ステップから増加した場合には交換操作を棄却する。 本研究では, 交換操作が 50 Monte Carlo ステップ連続 して棄却された時点で計算が収束したものと見なした.
上記の方法により統計的に再現された構造では，空 隙内に固体が孤立して浮かぶなど，物理的に起こりえ ない形状も存在しうる，そのため,このような形状に は Bentz and Martys ${ }^{(15)}$ の曲率による修正を施した.

この操作によって得られた三次元多孔質構造を図 6 に示す、計算領域は各方向 100 格子である. 上述の手 法によって, 元の二次元画像と定性的によく似た構造 が得られることがわかる.

構造再構築の妥当性を評価するため, 再構築構造と 元画像の構造統計量を比較した. 図 7 に示寸ように, 今回の収束判定条件下で再構築された構造の二点相関 は二次元画像のそれとほぼ一致しており，式(3)から 計算される残差は $1 \%$ 以下であった. さらに, 次式で 定義される Lineal-path function $L_{l}(r){ }^{(11)}$ の比較を行った. その結果を図 8 に示す.

$$
L_{i}(r)=\frac{l_{i}(r)}{N_{\text {pixel }}}
$$

ここで, $N_{\text {pixel }}$ は画素数もしくは格子数を表す，l(r)は 成分 $i$ 内部で長さ $r$ を有する線要素の個数を表し， $L_{i}(r)$ はその密度を意味する. 図 8 から明らかなように, 再 構築後の Lineal-path function は元画像のものとほぼ一 致する. 以上から, 本手法により燃料極試料の構造の 統計的性質がよく再現されていると言える.

\section{4. 西烃性能計算手法}

4・1 計算モデル 害際の電極の作動条件をモデル化 するために, 再構築した燃料極の $x=0, x=L$ の外側に それぞれ集電材，YSZ 電解質の層を加えた。境界条 件が計算結果に影響を及ぼさないよう，集電材，電解 質の厚さはそれぞれ $1.78 \mu \mathrm{m}(10 \Delta x), 3.56 \mu \mathrm{m}(20 \Delta x)$ と した. また，スパン方向 $(y, z$ 方向)には周期的な構造 を仮定した.

計算負荷を小さくするため, 燃料は $\mathrm{H}_{2} / \mathrm{H}_{2} \mathrm{O}$ の二成
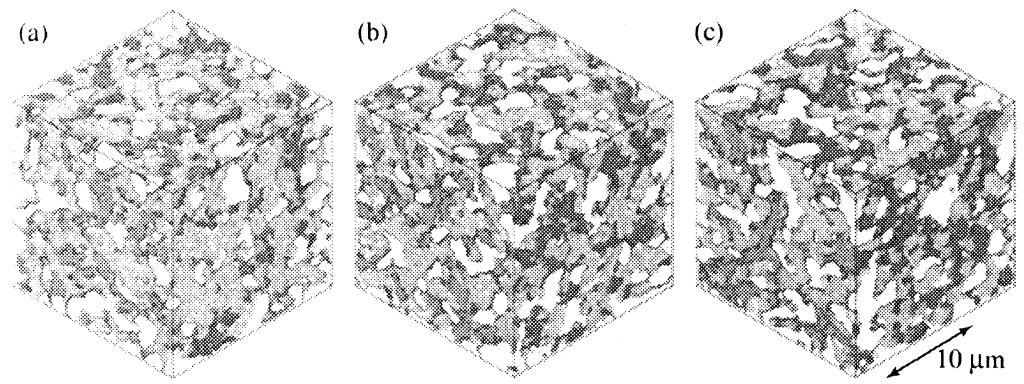

Fig. 6 Reconstructed anode microstructures sintered at (a) $1300{ }^{\circ} \mathrm{C}$, (b) $1350{ }^{\circ} \mathrm{C}$ and (c) $1400{ }^{\circ} \mathrm{C}$. White: $\mathrm{Ni}$, gray: YSZ, transparent gray: pore. 


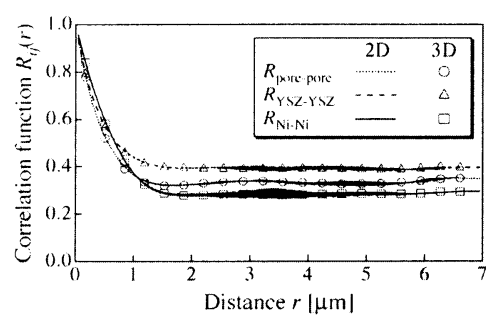

Fig. 7 Two-point correlation functions of original $2 \mathrm{D}$ image and reconstructed $3 \mathrm{D}$ structure $\left(1400^{\circ} \mathrm{C}\right.$ sintered sample).

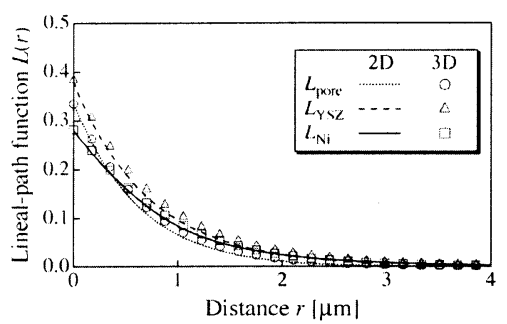

Fig. 8 Lineal-path functions of original $2 \mathrm{D}$ image and reconstructed $3 \mathrm{D}$ structure $\left(1400^{\circ} \mathrm{C}\right.$-sintered sample).

分系を仮定し, Chan and $\mathrm{Xia}^{\left({ }^{(1)}\right)}$ の等モル拡散の仮定を 用いて $\mathrm{H}_{2}$ の拡散のみを陽的に解いた. また, 計算領 域内で温度は一様とした。計算条件, 及び計算に用い た物性值を表 1 に示寸. なお，バイアス電流を印可し ない交流インピーダンス法による電極性能評価の文献 (19) との比較を行うため, 印加電流は微少量とした.

4・2 支町方程式 空隙, $\mathrm{Ni}, \mathrm{YSZ}$ 各相における支配 方程式は気体 $\left(\mathrm{H}_{2}\right)$ の拡散方程式, 電子, イオン導電 方程式であり，それぞれ以下の形で表される.

$$
\begin{aligned}
& \nabla(D \nabla C)=-\frac{1}{2 F} i_{\text {reac }} \\
& \nabla\left(\sigma_{\text {clec }} \nabla \phi_{\text {clec }}\right)=-i_{\text {reac }} \\
& \nabla\left(\sigma_{\text {เon }} \nabla \phi_{\text {ion }}\right)=i_{\text {reac }}
\end{aligned}
$$

ここで, $C$ は体積モル濃度 $\left[\mathrm{mol} / \mathrm{m}^{3}\right], \phi$ は電子または イオンの電位を表す. 各式の右辺は反応生成項を表し, 体積あたりの反応電流 $i_{\mathrm{rac}}$ は以下の Butler-Volmer 方程 式により与えられる(20).

$$
i_{\text {reac }}=i_{0} L_{\mathrm{TPB}}\left[\exp \left(\frac{2 F}{R T} \eta\right)-\exp \left(-\frac{F}{R T} \eta\right)\right]
$$

ここで, $\eta$ は過電圧 $\left(\phi_{\text {elec }}-\phi_{\text {on }}\right)$ である. 三相界面長 あたりの交換電流密度 $i_{0} は$, 多孔質 $\mathrm{Ni}$ 電極を用いた
Table 1 Simulation condition and physical properties.

\begin{tabular}{ll}
\hline Properties & Value or expression \\
\hline Operating temperature $T\left[{ }^{\circ} \mathrm{C}\right]$ & 1000 \\
Pressure $p[\mathrm{~Pa}]$ & $1.013 \times 10^{5}$ \\
Fuel composition $\left(\mathrm{H}_{2}: \mathrm{H}_{2} \mathrm{O}\right)[\mathrm{mol} \%]$ & $97: 3$ \\
Current density $i\left[\mathrm{~A} / \mathrm{cm}^{2}\right]$ & $1.0 \times 10^{-4}$ \\
Electronic conductivity $\sigma_{\mathrm{elec}}\left[\mathrm{Sm}^{-1}\right]^{(17)}$ & $3.37 \times 10^{6}-1065.3 T$ \\
Ionic conductivity $\sigma_{\mathrm{ion}}\left[\mathrm{Sm}^{-1}\right]^{188)}$ & $3.34 \times 10^{4} \exp \left(-\frac{10300}{T}\right)$ \\
Diffusion coefficient $D \mathrm{H}_{2}\left[\mathrm{~m}^{2} \mathrm{~s}^{-1}\right]$ & $5.59 \times 10^{-4}$ \\
Diffusion coefficient $D{ }_{\mathrm{H} 20}\left[\mathrm{~m}^{2} \mathrm{~s}^{-1}\right]$ & $3.47 \times 10^{4}$ \\
Equimolar diffusion coefficient $D\left[\mathrm{~m}^{2} \mathrm{~s}^{-1}\right]$ & $\frac{p_{\mathrm{H}_{2}}}{p} D_{\mathrm{H}_{2} \mathrm{O}}+\frac{p_{\mathrm{H}_{2} \mathrm{O}}}{p} D_{\mathrm{H}_{2}}$ \\
\hline
\end{tabular}

de Boer ${ }^{(21)}$ の実験結果から次式により与えた.

$$
i_{0}=31.4 \times p_{\mathrm{H}_{2}}^{-0.03} p_{\mathrm{H}_{2} \mathrm{O}}^{0.40} \exp \left(-\frac{1.83 \times 10^{4}}{T}\right)
$$

また, 式(8)中の $L_{\mathrm{TPB}}$ は体積あたり三相界面(TPB)長さ を表し, 再構築構造から算出した. その際, 滑らかな 曲線をボクセル外周と近似することで $L_{\mathrm{TPB}}$ が過大に 評価されるため, 三相界面長さはボクセル周長の $80 \%$ と仮定した。

4-3 計算手法 解析手法として, 境界条件の定式化 が容易な $\mathrm{LBM}^{(13)}$ を用いた。これは立方体格子上に離 散化された速度ベクトル $\mathbf{c}_{i}$ を有する粒子（気体, 電子 またはイオン）の速度分布関数 $f_{i}$ を追跡する計算手法 である. 拡散方程式の計算においては 3 次元 6 速度 （D3Q6）モデル（i=1～6）で十分な計算精度が得ら れることが知られており ${ }^{(22)}$, 本研究でも D3Q6 モデル を用いた. 衝突項に BGK 近似を用いると, 支配方程 式である格子ボルツマン方程式は以下の形で表される.

$$
\begin{aligned}
& f_{i}\left(\mathbf{x}+\mathbf{c}_{i} \Delta t, t+\Delta t\right)=f_{i}(\mathbf{x}, t) \\
& -\frac{1}{t^{*}}\left[f_{i}(\mathbf{x}, t)-f_{i}^{\mathrm{eq}}(\mathbf{x}, t)\right]+w_{i} \Delta t
\end{aligned}
$$

ここで, $f_{i}^{\mathrm{eq}}$ は Maxwell の平衡分布を表す.

$$
f_{i}^{\mathrm{eq}}(\mathbf{x}, t)=\frac{1}{6} \sum_{i=1 \sim 6} f_{i}(\mathbf{x}, t)
$$

また, 右辺の $w_{i} \Delta t$ は反応生成項であり, 式(5) (7)右 辺の生成項を各方向に対し分配することで計算される. また， $t$ は拡散係数 $D$ (または導電率 $\sigma)$ ，時間刻み 及び格子幅により定義される緩和時間であり，本研究 では $t^{*}=0.99$ となるように時間刻みを設定した.

境界条件として, $y, z$ 方向には周期境界条件を課し た.また，集電材側では気体の濃度を一定とし，集電 材，電解質境界面上でそれぞれ電子，イオン電流一定 の境界条件を課した，また，各相の境界面上では Halfway bounceback 則(23)を用いて二次精度の勾配なし 


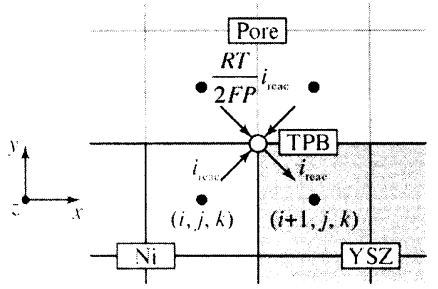

Fig. 9 Schematic of reaction production at TPB.

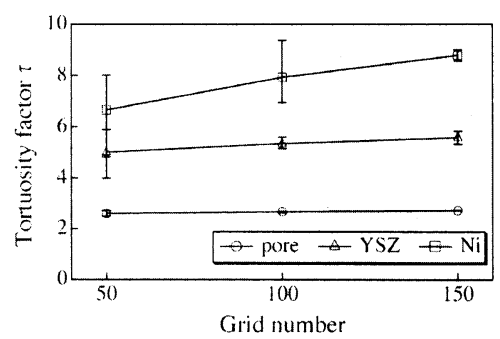

Fig. 10 Grid number dependence of tortuosity factors (1300 ${ }^{\circ} \mathrm{C}$-sintered sample).

\section{条件を課した.}

生成項の計算には, Mukherjee and Wang ${ }^{(12)}$ と類似の 手法を用い，三相界面局所での反応電流を計算した。 その概念図を図 9 に示す. 図 9 の場合, $(i+1 / 2, j+1 / 2, k)$ の三相界面で生じる反応電流は次式により計算される.

$$
\begin{aligned}
& i_{\text {rcaic }}\left(i+\frac{1}{2}, j+\frac{1}{2}, k\right)=i_{0} \times L_{\text {TPB }}\left(i+\frac{1}{2}, j+\frac{1}{2}, k\right) \\
& \times\left\{\exp \left(\frac{2 F}{R T} \eta\right)-\exp \left(-\frac{F}{R T} \eta\right)\right\} / \Delta x^{3} \\
& \eta=\phi_{\text {clec }}(i, j, k)-\phi_{\text {ion }}(i+1, j, k)
\end{aligned}
$$

式(12),(13)により計算された反応電流を隣接するセル に分配することで, 各セルでの反応生成量を計算した.

\section{5. 解析結果}

5・1 ネットワーク形成の評価 計算により得られた 有効扩散係数 $D^{\mathrm{eff}}$, 有効導電率 $\sigma^{\mathrm{eff}}$, 及び各成分の体積 分率عから，多孔質体の歪さを表す屈曲度ファクタてを 算出した. 従来, 屈曲度ファクタは多孔質内部の物質 輸送特性を評価するために用いられる值であるが，ネ ットワークの連続性を評価するために有用な指標であ るため, 本研究では固体内の電気伝導の評価にも $\tau$ を 用いた， $D^{\mathrm{eff}}$ または $\sigma^{\mathrm{eff}} と \tau と の$ 関係は次式で表される.

$$
\begin{aligned}
D^{\mathrm{cff}} & =\frac{\varepsilon}{\tau} D \\
\sigma^{\mathrm{elf}} & =\frac{\varepsilon}{\tau} \sigma
\end{aligned}
$$

定義より明らかなように，ての值が小さいほど良好な
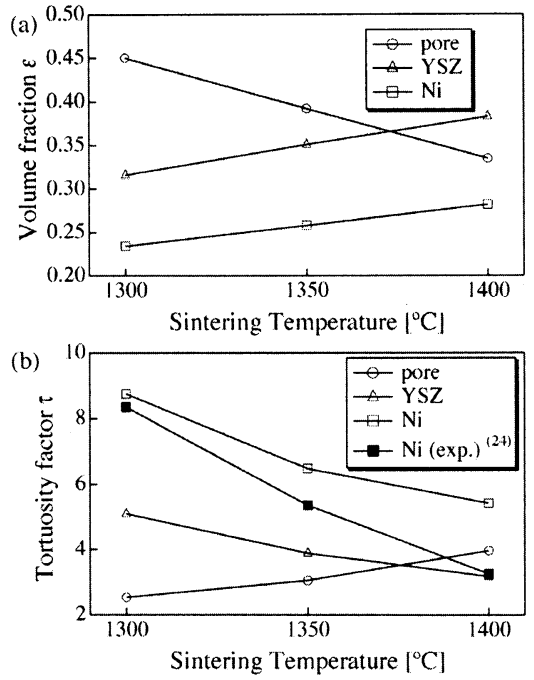

Fig. 11 Effect of sintering temperature upon (a) the volume fraction and (b) the tortuosity factor of each phase.

ネットワークが形成されていることを示す.

まず, 計算領域長 $L$ の異なる試料での拡散, 導電計 算の結果から, 計算領域長（格子数）の影響を評価し た. 計算対象は $1300{ }^{\circ} \mathrm{C}$ 焼結燃料極であり，全ての格 子数に対して 4 通りの異なる初期場から構造再構築を 行い，それぞれに対する屈曲度ファクタを LBM によ り求めた. 計算結果を図 10 に示す. 図中記号が 4 通 りの初期場に対する平均值を表し, エラーバーが得ら れた結果の範囲を表す。計算領域が小さい 50 格子(8.9 $\mu \mathrm{m})$ の場合は計算領域サイズと Ni クラスターのサイ ズがほぼ等しいため, 計算結果が大きなばらつきを示 す.これに対し，計算領域を 150 格子 $(26.7 \mu \mathrm{m})$ まで拡 大することにより, 全成分に対して屈曲度ファクタの ばらつきを $5 \%$ \%下まで低減できた，そのため，以下 の計算は全て 150 格子で行うものとする.

解析結果から得られた屈曲度ファクタの焼結温度依 存性を図 11 に示す. 図から, 体積分率の増加ととも に屈曲度ファクタの值が減少し, 粒子間ネットワーク の連続性が向上していることがわかる. また, $1400{ }^{\circ} \mathrm{C}$ 焼結時の $\mathrm{Ni}$ における屈曲度ファクタの值は体積分率 に比して小さく，焼結時の粒成長によりネットワーク が成長していることが確認できる.

比較のため，四端子法により測定した実際の試料に おける $\mathrm{Ni}$ 相の屈曲度ファクタ(24)を図 11 に併記する. 本手法により推測された $\mathrm{Ni}$ 相の屈曲度ファクタは実 測值より大きな值を示すが，高温焼結によるネットワ 一クの成長が定性的に良く再現されていると言える. また, 空隙の屈曲度ファクタに関しても, 文献值(2.5 


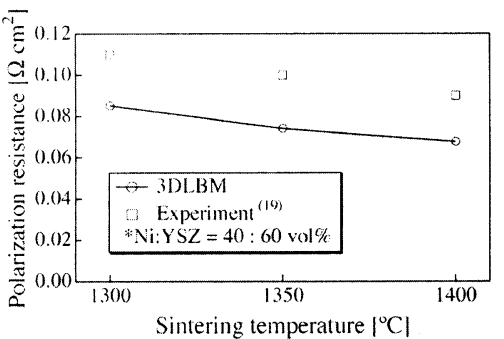

Fig. 12 Effect of sintering temperature upon the anodic polarization resistance (comparison with literature data).

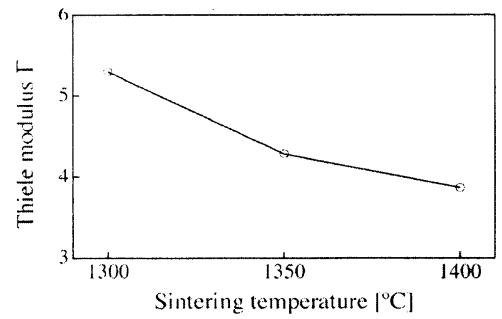

Fig. 13 Sintering temperature dependence of the Thiele modulus $\Gamma$.

$4.0)^{(25)}$ との良好な一致が得られており，これらの結果 から本手法の妥当性が示される.

5 - 2 燃料極過压の評価計算結果から得られた然 料極活性化抵抗の焼結温度依存性を図 12 に示す.図 から，今回の焼結温度範囲では焼結温度とともに活性 化抵抗が減少することがわかる．これは，焼結温度の 影響を実験的に調べた研究例 ${ }^{(19)(26)}$ と一致し, 特に燃料 極組成が近い Primdahl et al. ${ }^{(19)}$ の実験結果(Ni：YSZ = $40: 60$ vol\%)と良い一致が得られた.

上述の過電圧の変化を, 次式で定義される無次元数 「 (27)を用いて考察する.

$$
\Gamma^{2}=\frac{3 i_{1} L_{\mathrm{TPB}} F\left(\rho_{\mathrm{ion}}^{\mathrm{eff}}+\rho_{\mathrm{elec}}^{\mathrm{etf}}\right)}{R T} L^{2}
$$

ここで，Lは電極厚さである. 式(16)は式(6)-(8)を過 電压に関して連立, 線形化することで導出され, オ一 么抵抗と活性化抵抗の比を表す。 また，物質輸送との アナロジ一から「は Thiele 数と呼称される. 一般に, $\Gamma>3$ の場合は才一ム抵抗支配となり, 反応に有効な 電極厚さはГに反比例する。そのため,この場合には 過電圧と各パラメータの間に次の関係式が成り立つ ${ }^{(27)}$.

$$
\eta \propto \Gamma / L_{\mathrm{TPB}} i_{0} \propto \sqrt{\rho_{\mathrm{ion}}^{\mathrm{eff}} / L_{\mathrm{TPB}} i_{0}}
$$

なお， SOFC 燃料極において電子抵抗はイオン抵抗に 比して十分小さいため無視した.

Thiele 数の焼結温度依存性を図 13 に示す.今回の 計算条件下では，いずれの試料とも $\Gamma>3$ となりオー

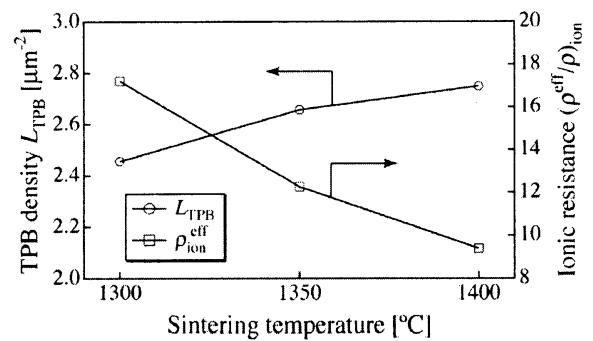

Fig. 14 Sintering temperature dependence of the TPB density and the ionic resistance.

ム抵抗が支配的となっていることがわかる. 式(17)に 示したように，この条件下では過電圧は三相界面密度 と有効イオン抵抗率に依存する. 本解析により得られ た各試料の三相界面密度, 及び有効イオン抵抗率を図 14 に示す. 焼結温度とともに三相界面密度が増加し, 有効イオン抵抗率は減少する. 式(17)から，これによ り活性化抵抗が低減するものと考えられる.

また, 浸透理論, 配位数理論に基づく Nam and Jeon のモデル(28), 及び今回の材料条件から計算される三相 界面密度は $1.7 \sim 2.1 \mu \mathrm{m}^{-2}$ であり, 今回の結果と比較的 良く一致していると言える.

\section{6. 倛}

焼結温度の異なる燃料極試料の微細構造を再現し, その電極性能を評価するため, 確率的構造再構築法と 格子ボルツマン法を組み合わせた新たな電極シミュレ ーションを行い，以下の知見を得た.

1) 重み付き輪郭強調演算を施したレーザ顕微鏡画像 から, SOFC 燃料極の各成分の判別が可能である.

さらに，収束演算による構造再構築手法を用いる ことで，二点相関と Lineal-path function を再現した 三次元構造の再構築が可能である.

2)再構築された三次元構造を用いて, LBM による数 值シミュレーションを行ったところ, 屈曲度ファ クタの焼結温度依存性が再現できた. LBM から得 られた Ni 相の屈曲度ファクタは実験值より大きな 值を示すが，高温焼結によるネットワークの成長 が定性的に良く再現された。

3) 本報の焼結温度範囲では, 高温焼結試料ほど高い 発電性能を示すことが確認された。これは, 焼結 温度の上昇とともに三相界面密度が増加し, 有効 イオン抵抗率が減少したためである。 また, 本解 析結果は材料組成の近い類似の実験結果と良好な 一致を示し, 本手法の妥当性が示された. 本報で提案した解析手法では, 従来の解析手法と 
異なり，三相界面長さあたりの交換電流密度の他には 経験式を用いることなく電極性能を直接計算すること が可能である，そのため，今回提案した手法は燃料極 微細構造の最適化に向けた有用な手法と言える.

\section{碀辞}

本研究は文部科学省 21 世紀 COE プログラム“機 械システム・イノベーション”の支援を受けた。 また， 本研究を進めるにあたり，東京大学大学院鈴木雄二助 教授, 同深潟康二助手に有益なご助言を頂いた. また, 試料の作成, データ取得に関しては東京大学大学院修 土:課程山口悠氏，坂本雄祐氏にご協力頂いた。記して 謝意を表する.

\section{文献}

(1) Singhal, SC. and Kendall, K., High Temperature Solid Oxide Fuel Cells, Elsevier (2002).

(2) Uechi, H. et al., Cycle Analysis of Gas Turbine-Fuel Cell Hybrid Micro Generation System, ASME J. Eng. Gas Turbines and Power, 126 (2004), pp. 755-762.

(3) Chan, SH. et al., A complete polarization model of a solid oxide fuel cell and its sensitivity to the change of cell component thickness, J. Power Sources, 93 (2001), pp. 130-140.

(4) Abe, H. et al., Microstructural control of Ni-YSZ cermet anode for planar thin-film solid oxide fuel cells, Thin Solid Films, 496 (2006), pp. 49-52.

(5) Koide, H. et al., Properties of Ni/YSZ cermet as anode for SOFC, Solid State Ionics, 132 (2000), pp. 253-260.

(6) Costamagna, P. et al., Micro-modeling of solid oxide fuel cell electrodes, Electrochimica Acta, 43 (1998), pp. 375-394.

(7) Sunde, S., Monte Carlo Simulations of Polarization Resistance of Composite Electrodes for Solid Oxide Fuel Cells, J. Electrochem. Soc., 143 (1996), pp. 1930-1939.

(8) Lee, JH. et al., Quantitative analysis of micro structure and its related electrical property of SOFC anode, Ni-YSZ cermet, Solid State Ionics, 148 (2002), pp. 15-26.

(9) Wilson, JR et al., Three-dimensional reconstruction of a solid-oxide-fuel-cell anode, Nature Materials, 5 (2006), pp541-544.

(10) Quiblier, JA., A New Three-Dimensional Modeling Technique for Studying Porous Media, J. Colloid and Interface Sci., 98 (1984), pp. 84-103.

(11) Yeong, CLY. and Torquato, S., Reconstructing random media. II. Three-dimensional media from two-dimensional cuts, Phys. Rev. E., 58 (1998), pp. 224-233.
(12) Mukherjee, PP. and Wang, CY., Stochastic Microstructure Reconstruction and Direct Numerical Simulation of the PEFC Catalyst Layer, $J$. Electrochem Soc., 153 (2006), pp. A840-A849.

(13) Chen, S. and Doolen, GD., Lattice Boltzmann Method for Fluid Flows, Annu. Rev. Fluid Mech., 30 (1998), pp. 329-364.

(14) Lee, KR. et al., Viable image analyzing method to characterize the microstructure and properties of the $\mathrm{Ni} /$ YSZ cermet anode of SOFC, J. Power Sources, 140 (2005), pp. 226-234.

(15) Bentz, DP. and Martys, NS., Hydraulic Radius and Transport in Reconstructed Model ThreeDimensional Porous Media, Transport in Porous Media, 17 (1994), pp.221-238

(16) Chan, SH. and Xia, ZT., Anode Micro Model of Solid Oxide Fuel Cell, J. Electrochem Soc., 148 (2001), pp. A388-A394.

(17) Anselmi-Tamburini, U. et al., Electrical properties of $\mathrm{Ni} / \mathrm{YSZ}$ cermets obtained through combustion synthesis, Solid State Ionics, 110 (1998), pp. 35-43.

(18) Ferguson, JR. et al., Three-dimensional numerical simulation for various geometries of solid oxide fuel cells, J. Power Sources, 110 (2002), pp. 91-95.

(19) Primdahl, S. et al., Effect of $\mathrm{Ni}$ Oxide/YttriaStabilized Zirconia Anode Precursor Sintering Temperature on the Properties of Solid Oxide Fuel Cells, J. Am. Ceram. Soc., 83 (2000), pp. 489-494.

(20) Kawada, T. et al., Characteristics of Slurry-Coated Nickel Zirconia Cermet Anodes for Solid Oxide Fuel Cells, J. Electrochem Soc., 137 (1990), pp. 30423047.

(21) De Boer, B., SOFC Anode, Ph. D. thesis, Univ. of Twente, The Netherland (1998).

(22) Zeiser, TH. et al., CFD-calculation of flow, dispersion and reaction in a catalyst filled tube by the lattice Boltzmann method, Chem. Eng. Sci., 56 (2001), pp. 1697-1704.

(23) Gallivan, MA. et al., An evaluation of the bounceback condition for Lattice Boltzmann simulations, Int. J. for Numerical Methods in Fluids, 25 (1997), pp. $249-263$

(24) Yamaguchi, Y., private communication (2007).

(25) Williford, RE. et al., Diffusion Limitation in the Porous Anodes of SOFCs, J. Electrochem. Soc., 150 (2003), pp. A1067-A1072.

(26) Jiang, SP., A Comparative Study of Fabrication and Performance of $\mathrm{Ni} / 3$ mol\% $\mathrm{Y}_{2} \mathrm{O}_{3}-\mathrm{ZrO}_{2}$ and $\mathrm{Ni} / 8$ mol\% $\mathrm{Y}_{2} \mathrm{O}_{3}-\mathrm{ZrO}_{2}$ Cermet Electrodes, J. Electrochem. Soc., 150 (2003), pp. E548-E559.

(27) Costamagna, P. et al., Some more considerations of the optimization of cermet solid oxide fuel cell electrodes, Electrochimica Acta, 43 (1998), pp. 967972.

(28) Nam, JH. and Jeon, DH., A comprehensive microscale model for transport and reaction in intermediate temperature solid oxide fuel cell, Electrochimica Acta, 51 (2006), pp. 3446-3460. 